\title{
Determination of Nicotine Extracted from Eggplant and Green Pepper by HPLC
}

\author{
Zeinab Hashim Mohammed
}

Received 22/1/2018, Accepted 26/9/2018, Published 11/3/2019

$\Theta$

\begin{abstract}
:
Nicotine was separated from eggplant and green pepper seeds (Solanaceous) by High Performance Liquid Chromatography (HPLC).The concentration of nicotine in the eggplant extract $(0.871-0.877 \mu \mathrm{g} / \mathrm{ml})$ was determined by injecting standard material with 0.5 and $1.5 \mu \mathrm{g} / \mathrm{ml}$, while the concentrations of nicotine in green pepper extract $(0.613-0.618 \mu \mathrm{g} / \mathrm{ml})$ was determined when the standard material was injected with 0.5 and $1.5 \mu \mathrm{g} / \mathrm{ml}$. The qualitative chemical data was calculated from derivations of the standard material. Nicotine concentration was measured qualitatively in both extracts through the calibration curve and method of the standard addition. This technique has high accuracy and compatibility, bringing the proportion of relative recovery percentage of nicotine extracted from eggplant seeds to $95.880-103.104 \%$ and relative error of -4.119-3.104\%. Relative recovery percentage of nicotine extracted from green pepper seeds was 97.284 $103.518 \%$ and relative error was $-2.716-3.518 \%$.
\end{abstract}

Keywords: Eggplant, Extracted, Green Pepper, HPLC, Nicotine

\section{Introduction:}

\section{Nicotine}

approximately $0.6-3.0 \%$ of the dry weight of modern tobacco (1). It also occurs in edible plants of the Solanaceae family, which includes eggplant, potatoes, green pepper and tomatoes but under 200 nanograms per gram, dry weight (less than $0.0002 \%$ ) (2). At high doses nicotine is associated with poisonings and is potentially lethal $(3,4)$. Nicotine is linked to possible birth defects(5). During pregnancy, there are increased risks for type two diabetes, obesity, hypertension, dysfunction and infertility (4).Nicotine can be quantified in blood, plasma, or urine to confirm poisoning or to facilitate a forensic autopsy. Urinary or salivary concentrations are frequently measured for the purposes of pre-employment and health insurance medical screening programs(6).

There is effect of bacteria on some diseases which injure the Solanaceae family(7). Nicotine have a clear antibiotic effect on bacteria and fungi $(8,9,10)$.

Nicotine extracts can be utilized as alternative fungicides $(11,12)$.

The chemical structure of nicotine $\left(\mathrm{C}_{10} \mathrm{H}_{14} \mathrm{~N}_{2}\right)$, nicotine is crewed from two cycles (Pyridine, Pyrrolidine) (13)and is shown in fig.1.

Applied Chemistry Department, College of Applied

Sciences, University of Samarra, Samarra, Iraq

E-mail: Zainab.h@uosamarra.edu.iq

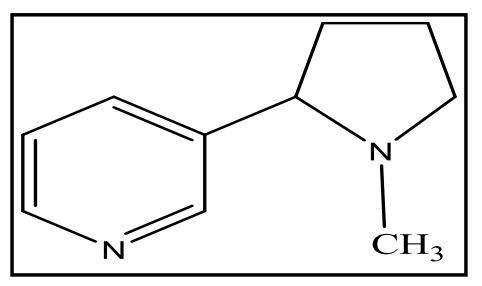

Figure 1. Chemical structure of nicotine

There are different ways to identify and quantify nicotine typically in blood and urine by RP-HPLC and GC-MS(14) or from plant matter HPLC(15). Separation of nicotine from cigarettes can be accomplished by TLC(16).

-Here, we separate and quantify nicotine from eggplant and green pepper seed extraction.

-We were able to obtain a quantitative estimation by HPLC and U.V. after preliminary qualitative analysis.

\section{Materials and Methods:}

Table 1 shows the chemical materials and their global origin which were used. 
Table 1.Chemical Materials

\begin{tabular}{|c|c|c|c|c|}
\hline No. & Material & $\begin{array}{c}\text { Purity } \\
\%\end{array}$ & $\begin{array}{l}\text { Chemical } \\
\text { Formula }\end{array}$ & Company \\
\hline 1. & Ethanol & 99.9 & $\mathrm{C}_{2} \mathrm{H}_{5} \mathrm{OH}$ & Scharlau \\
\hline 2. & Methanol & 99.5 & $\mathrm{CH}_{3} \mathrm{OH}$ & Scharlau \\
\hline 3. & Sulfuric acid & 98 & $\mathrm{H}_{2} \mathrm{SO}_{4}$ & $\mathrm{BDH}$ \\
\hline 4. & $\begin{array}{l}\text { Ammonium } \\
\text { Hydroxide }\end{array}$ & 25 & $\mathrm{NH}_{4} \mathrm{OH}$ & $\mathrm{BDH}$ \\
\hline 5. & Chloroform & 99.4 & $\mathrm{CHCl}_{3}$ & MERCK \\
\hline 6. & Nicotine & 99.9 & $\mathrm{C}_{10} \mathrm{H}_{14} \mathrm{~N}_{2}$ & Sigma. Ik \\
\hline 7. & $\begin{array}{l}\text { Mercuric } \\
\text { Chloride }\end{array}$ & 99 & $\mathrm{HgCl}_{2}$ & BDH \\
\hline 8. & $\begin{array}{l}\text { Potassium } \\
\text { Iodide }\end{array}$ & 99.5 & KI & Sigma \\
\hline
\end{tabular}

The extraction of nicotine alkaloids was accomplished by the following protocol (17):

1-Weight $10 \mathrm{gm}$ of dried powdered seeds of both eggplant (Solanum melongena) and green pepper (Capsicum annuum).

2-Add 200ml ethanol in soxhlet to the powdered seeds.
3-Concentrate the extraction by rotary evaporation at $40^{\circ} \mathrm{C}$ for 6 hours.

4-Dissolve dried substance in $5 \mathrm{ml}$ ethanol and add $30 \mathrm{ml}$ of sulfuric acid to the extraction.

5-Evaporate ethanol using rotary evaporator to get rid of acid solution and add ammonium hydroxide $10 \%$ to until the solution reaches a $\mathrm{pH}$ of $=9$.

6-Put solution in separation funnel adding chloroform, and concentrate in rotary evaporator.

7 -Dry extraction at $50^{\circ} \mathrm{C}$.

8- Add $5 \mathrm{ml}$ of $10 \%$ ammonia solution and $5 \mathrm{ml}$ $95 \%$ methanol to $5 \mathrm{gm}$ of dried extraction.

9-Put extraction in shaker water bath in $60^{\circ} \mathrm{C}$ for 15 mints. Cool and filter using Watman no.11 filter paper.

10-Concentrate the filtrates in a vacuum rotary evaporator until it reaches $1 \mathrm{ml}(18)$. Fig.(2) explain the steps of extraction method.

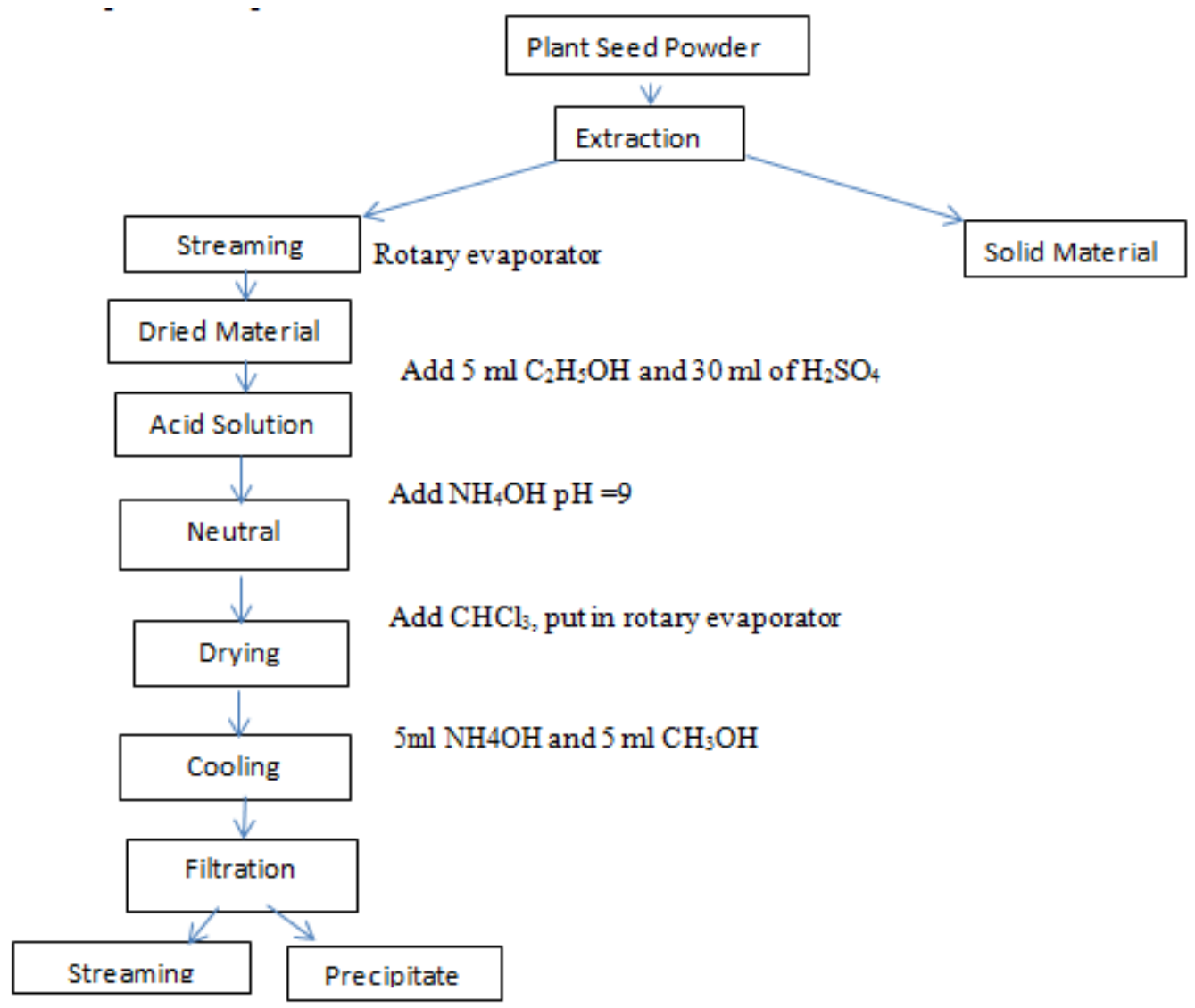

Figure 2. Shows the extraction of nicotine from the seeds of eggplant and green pepper

Preliminary Qualitative Screening (19, 20) reagent for Alkaloids

Mayers' reagent is prepared by using solution A+B as follows.

Solution (A) is prepared as follows

Dissolve $1.4 \mathrm{gm}$ from mercuric chloride in $60 \mathrm{ml}$ of distilled water.

Solution (B) is prepared as follows

Dissolve $5 \mathrm{gm}$ of potassium iodide in $10 \mathrm{ml}$ of distilled water.
Mix two solutions $\mathrm{A}+\mathrm{B}$ and add distilled water until the volume reaches $100 \mathrm{ml}$.

Take $1 \mathrm{ml}$ of the extract and add drops of the reagent.

A white colour or off white residual is made when the alkaloid is present.

Wagners' reagent is prepared as follows.

Dissolve $2 \mathrm{gm}$ of potassium iodide in $20 \mathrm{ml}$ of distilled water. 
Add $1.3 \mathrm{gm}$ of $\mathrm{I}_{2}$. Mix well until dissolving. Add distilled water until volume of $100 \mathrm{ml}$ is reached.

Take $1 \mathrm{ml}$ of the extract and add drops of the reagent to the extract. A yellow color or sepia color residual is made which indicates the presence of an alkaloid. The Standard Calibration Curve for Nicotine

Nicotine solution is prepared in concentrations of $5,10,15,25,35,50 \mathrm{ppm}$ from nicotine solution in $100 \mathrm{ppm}$ in $100 \mathrm{ml}$ volume bottles. Absorption is measured in $254 \mathrm{~nm}$ an opposite blank solution of ethanol.

\section{The Standard Addition Method (21)}

The standard addition method was used for several concentrations in the analysis of nicotine extract and increasing volumes of the standard nicotine solution (100 ppm). The additives were added in Table 2 and absorption was measured at $254 \mathrm{~nm}$. The method with the concentration is taken directly by the calibration curve.

Table 2. Method of Standard Addition for Eggplant and Green Pepper Extract

\begin{tabular}{cccccc}
\hline $\begin{array}{c}\text { volume bottles } \\
\text { volume (5ml) }\end{array}$ & $\mathbf{S}$ & $\mathbf{1}$ & $\mathbf{2}$ & $\mathbf{3}$ & $\mathbf{4}$ \\
\hline $\begin{array}{c}\text { The volume of } \\
\text { eggplant seeds } \\
\quad \text { extracts }\end{array}$ & 0.5 & 0.5 & 0.5 & 0.5 & 0.5 \\
$\begin{array}{c}\text { The volume green } \\
\text { pepper seeds extracts } \\
\begin{array}{c}\text { Standard solution } \\
\text { volume }\end{array}\end{array}$ & 0.5 & 0.5 & 0.5 & 0.5 & 0.5 \\
\hline
\end{tabular}

Quantitative Determination of Nicotine in Eggplant and Green Pepper by HPLC

The main compound is separated on FLC (22) (Fast Liquid Chromatographic) column under the following conditions: Column: Phenomenex C$18,3 \mu \mathrm{m}$ Particle size ( $50 \times 4.5 \mathrm{~mm}$ I.D) column. The mobile phase is: $0.01 \mathrm{M}$ potassium phosphate buffer pH 3.2: methanol HPLC grade (80:30,V/V)with a flow rate $1.2 \mathrm{ml} / \mathrm{min}$. Detection was of UV light at $254 \mathrm{~nm}$ with an injection volume of $100 \mu \mathrm{l}$.

The unknown concentrations were calculated according to the following law:

Concentration of Sample $\mu \mathrm{g} / \mathrm{ml}=\frac{\text { area of sample }}{\text { area of }} \times$ Conc.
Of Standard $x$ dilution Factor The separation occurfed ondard liquid chromatography Shimadzu 10 AV-LC equipped with binary delivery pump model LC-10A shim adze, and the eluted peaks were monitored by UVVis 10 A- SPD spectrophotometer.

The extract were centrifuged at 7,500 rpm for $15 \mathrm{~min}$. The extract samples were re-suspended in $1.0 \mathrm{ml} \mathrm{HPLC}$ grade methanol by overtaxing. The mixture were passed through $2.5 \mathrm{um}$ disposable filter, and stored at $4^{\circ} \mathrm{C}$ for further analysis and then $100 \mu$ l of the sample injected into HPLC system according the optimum condition.

\section{Results and Discussion:}

Qualitative and Quantitative Analysis

The Preliminary Qualitative Screening on Nicotine extract eggplant and green pepper seeds and Table 1 shows the follwing screening results:

Table 3. Results of Screening on Nicotine Extract From Eggplant and Green Pepper Seeds

\begin{tabular}{ccc}
\hline \multicolumn{1}{c}{ Test } & Eggplant & Green Pepper \\
\hline Mayers' test & + & + \\
Wagners' test & + & + \\
\hline
\end{tabular}

Both reagents detected alkaloids, and specifically nicotine, in the eggplant and green pepper seeds (11).

The nicotine calibration curve was prepared as described in the materials and methods. Absorption was measured at $254 \mathrm{~nm}$ for concentrations of 5-50 ppm and the absorption values were measured against the concentration as show in Fig. 3.

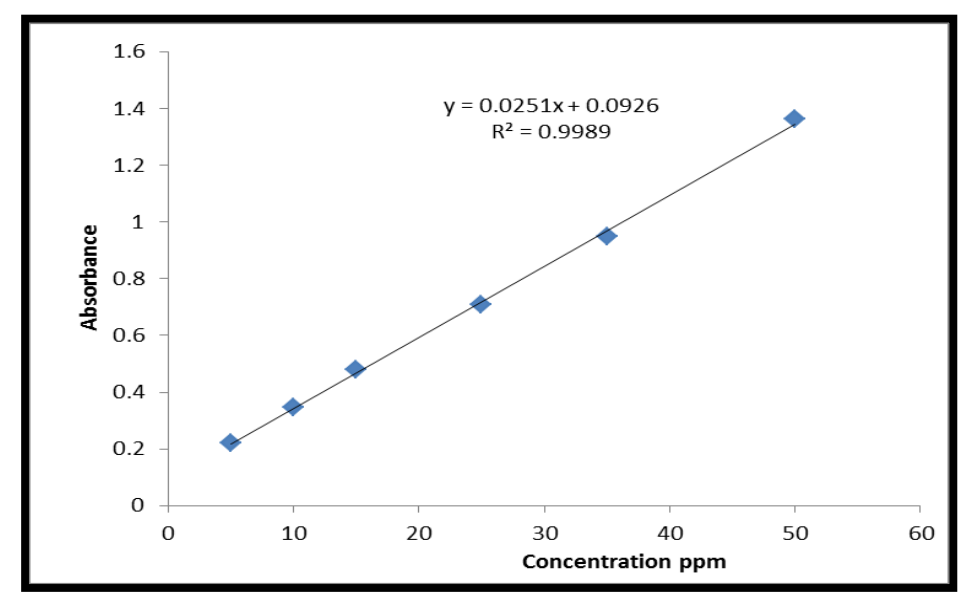

Figure 3. The Standard Curve of Nicotine 
The accuracy and compatibility of the standard nicotine was tested by the relative recovery percentage and percentage relative error calculated.
The method was accurate and compatible with recovery of $97.370-103.108 \%$ and error of -2.629$3.108 \%$ of nicotine as shown in Table 4.

Table 4. Accuracy and Compatibility of the Method to Estimate Nicotine

\begin{tabular}{ccccc}
\hline Concentration taken $(\mathbf{p p m})$ & Absorbance average & Concentration found $(\mathbf{p p m})$ & Err\% & Rec\% \\
\hline 5 & 5.155 & 0.222 & 3.108 & 103.108 \\
10 & 10.056 & 0.345 & 0.558 & 100.558 \\
15 & 15.355 & 0.478 & 2.364 & 102.364 \\
25 & 24.518 & 0.708 & -1.928 & 98.072 \\
35 & 34.079 & 0.948 & -2.629 & 97.370 \\
50 & 50.573 & 1.362 & 1.147 & 101.147 \\
\hline
\end{tabular}

The method of standard additions was used to analyze nicotine extracted from eggplant seeds as shown in the work method. Absorption was measured at $254 \mathrm{~nm}$ for concentrations of 0-40 ppm and the absorption values of concentration were calculated as in Fig. 4.

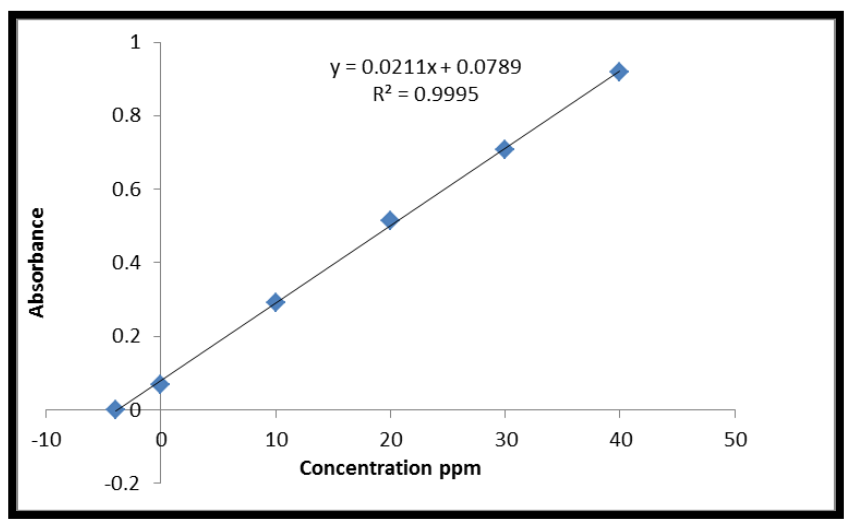

Figure 4. Standard curved additions of nicotine extract from eggplant seeds

The accuracy and compatibility of the standard additions of nicotine extracted from the eggplant seeds were tested by calculating recovery percentage and of 95.880-103.104\% and error of 4.119- $3.105 \%$ as shown in Table 5.

Table 5. Accuracy and Compatibility Method of Standard Addition of Nicotine Extracted from Eggplant Seeds

\begin{tabular}{ccccc}
\hline Concentration taken(ppm) & Absorbance average & Concentration found (ppm) & Err\% & Rec\% \\
\hline 3.9 & 3.739 & 0 & -4.119 & 95.880 \\
0 & 0.5166 & 0.068 & - & - \\
10 & 10.052 & 0.291 & 0.521 & 100.521 \\
20 & 20.621 & 0.541 & 3.105 & 103.104 \\
30 & 29.815 & 0.708 & -0.616 & 99.384 \\
40 & 39.720 & 0.917 & -0.699 & 99.301 \\
\hline
\end{tabular}

The method of standard additions was used to analyze nicotine extracted from green pepper seeds as shown in the methods above. Absorption is measured at $254 \mathrm{~nm}$ for concentrations $0-40 \mathrm{ppm}$ and the absorption values concentration are calculated as show in Fig. 5.

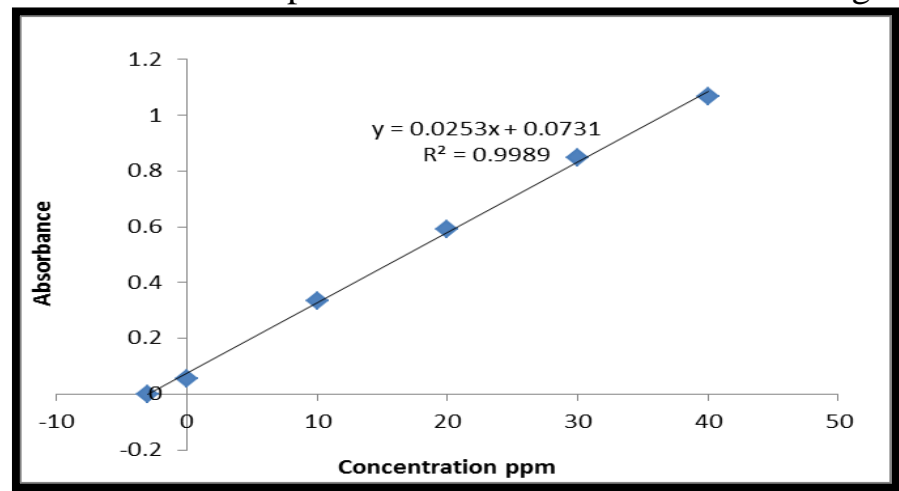

Figure 5. Standard curved additions of nicotine extract from green pepper seeds 
The accuracy and compatibility of the standard additions of nicotine extracted from the green pepper seeds were tested by calculating recovery percentage and relative error percentage.
The method was found to be highly accurate and compatible, with $97.284-103.518 \%$ and error of 2.716- $3.518 \%$ as shown in Table 6

Table 6. Accuracy and compatibility method of standard addition of nicotine extracted from green pepper seeds

\begin{tabular}{ccccc}
\hline Concentration taken(ppm) & Absorbance average & Concentration found(ppm) & Err\% & Rec\% \\
\hline 2.97 & 2.889 & 0 & -2.716 & 97.284 \\
0 & 0.715 & 0.055 & - & - \\
10 & 10.352 & 0.335 & 3.518 & 103.518 \\
20 & 20.509 & 0.592 & 2.549 & 102.549 \\
30 & 30.588 & 0.847 & 1.963 & 101.963 \\
40 & 39.363 & 1.069 & -1.590 & 98.409 \\
\hline
\end{tabular}

\section{HPLC}

The analysis results by HPLC of nicotine extracted from eggplant seeds refers to the appearance of many peaks. One of them was identical to the

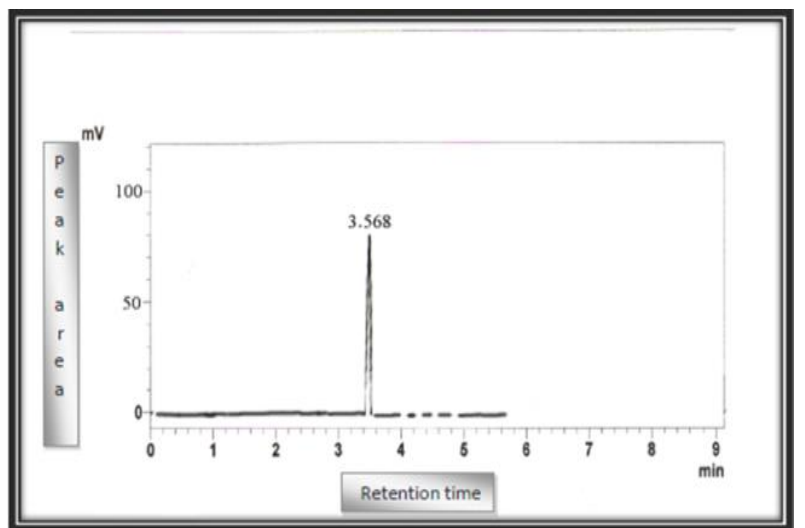

Figure (6) Analysis of HPLC for Standard

Nicotine with Concentration $(0.5 \mu \mathrm{g} / \mathrm{ml})$ standard compound at 0.5 and $1.5 \mu \mathrm{g} / \mathrm{ml}$ from the standard. Its concentration was $0.871-877 \mu \mathrm{g} / \mathrm{ml}$, as seen in Tables $(7,8)$ and Figs. $(6,7,8)$.

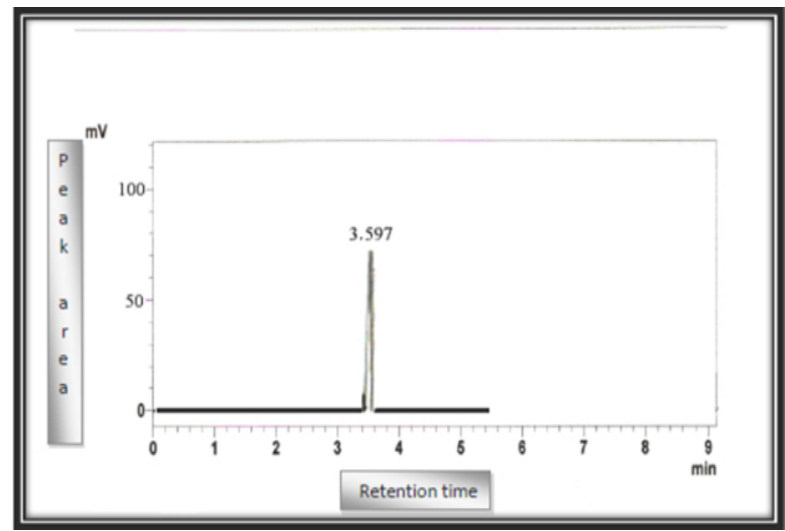

Figure (7) Analysis of HPLC for Standard Nicotine with Concentration $(1.5 \mu \mathrm{g} / \mathrm{ml})$

Table 7. Concentration of standard and retention time

\begin{tabular}{cccc}
\hline Subjects & Retention time $($ minute $)$ & Area $(\boldsymbol{\mu}$ volt $)$ & Concentration $\boldsymbol{\mu g} / \mathbf{m l}$ \\
\hline Nicotine & 3.597 & 25742 & 0.5 \\
Nicotine & 3.568 & 76633 & 1.5 \\
\hline
\end{tabular}

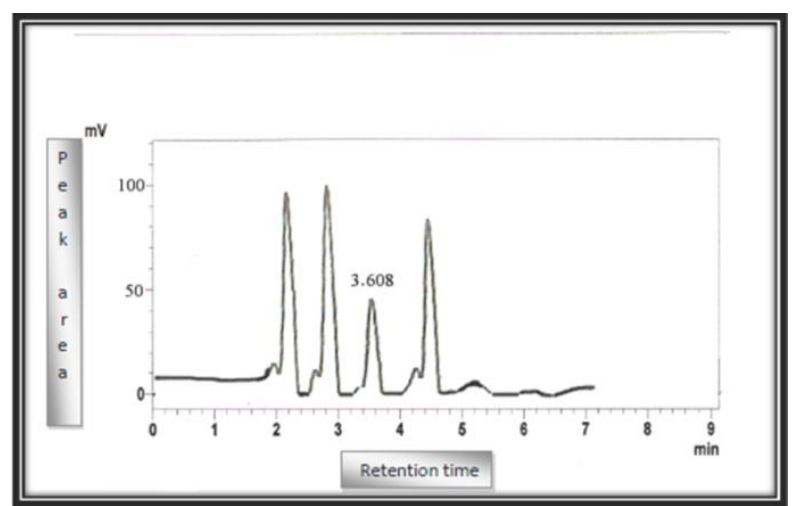

Figure 8. Analysis of HPLC to separated nicotine from eggplants seed extract
Table 8. Retention time and peak area from extract eggplants seeds

\begin{tabular}{cccc}
\hline $\begin{array}{c}\text { Concentration } \\
\boldsymbol{\mu g} / \mathbf{m l}\end{array}$ & $\begin{array}{c}\text { Peak } \\
\text { area }\end{array}$ & $\begin{array}{c}\text { Retention } \\
\text { time(minute) }\end{array}$ \\
\hline 0.5 & 0.871 & 44845 & 3.608 \\
1.5 & 0.877 & 4484 & \\
\hline
\end{tabular}

The HPLC results from green pepper seeds refers to the appearance of many peaks. One of them is identical to the standard compound. Its concentration was $0.613-0.618 \mu \mathrm{g} / \mathrm{ml}$, as seen in Tables $(7,9)$ and Figs. $(6,7,9)$. 


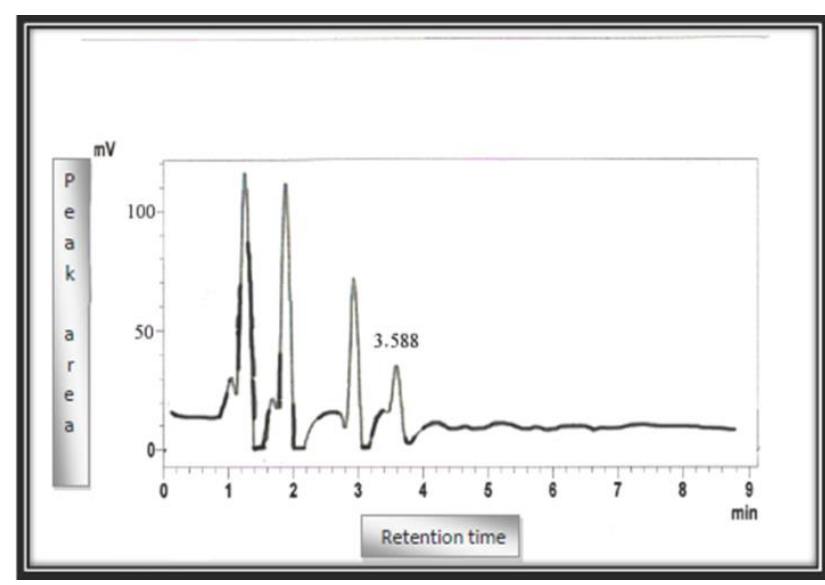

Figure 9. HPLC readout of green pepper seed extract

In figs. 8 and 9 the peak doesn't appear under base line, we give direction to the decatur, so as not to record the pack on $5000 \mathrm{UV}$. Any area more than 5000 UV appears as a retention time and area. As long as retention time of material identical for standard compound was detected the sample. It is also quantities calculated as the area.

Table 9. Retention Time and Peak Area Separated of Nicotine from Green Pepper Seed Extract

\begin{tabular}{cccc}
\hline \multicolumn{2}{c}{ Concentration $\boldsymbol{\mu g} / \mathbf{m l}$} & $\begin{array}{c}\text { Peak } \\
\text { area }\end{array}$ & $\begin{array}{c}\text { Retention } \\
\text { time(minute) }\end{array}$ \\
\hline 0.5 & 0.613 & 31580 & 3.588 \\
1.5 & 0.618 & & \\
\hline
\end{tabular}

Through tables $(8,9)$ and figures $(7,8)$, it was concluded that nicotine appeared in eggplant and green pepper seed extracts. It can be concluded that Solanaceous plants contain nicotine and it can be determined by HPLC(12).

\section{Conclusion:}

The method of separation of nicotine extracted from Solanaceous and quantitatively assessed by qualitative and spectral method and HPLC technique. The concentration of nicotine in the eggplant and green pepper extract was found to be close after comparing with different concentrations of the standard material.

\section{Conflicts of Interest: None.}

\section{References:}

1. GA Giovino, SA Mirza, J M Samet, P C Gupta, M J Jarvis. Smoking and Tobacco control Monograph No.9 (PDF). Retrieved. 2012.

2. Moldoveaun, Serban C.; Scott, Wayne A, Lawson, Darlene M. Nicotine Analysis in Several NonTobacco Plant Materials. Beitrage Zur Tabakforschung .2016.
3. Mayer B. How much nicotine Kills a Human? Tracing back the generally accepted lethal dose to dubious self-experiments in the nineteenth century " Arch. Toxicol. . 2014; 88(1):5-7.

4. Schraufngel, Dean E, Blasi Francesco, Drummond, M. Bradley, Lam David CL, Latif, Ehsan, Rosen, Mark J, Sansores, Raul, Van Zyl-smit, Richard. Electronic Cigarettes. A Position Statement of the Forum of International Respiratory Societies .Am J Respir Crit Care Med .2014;190 (6) : 611-618.

5. Jerry JM, Collins GB, Streem D. E-cigarettes: Safe to recommend to patients?. Cleve Clin J Med.2015; 82 (8): 521.

6. Baselt, Randall Clint. Disposition of Toxic Drugs and Chemicals in Man (10 th ed.) Biomed. Pub. 2014; pp. 140 .

7. Mahmod Emad Ahmad, Saleh. Hussam Al-Din Abdulla Mohamed, Hameed. Aliaa Abul-Azeez. The effect of Bacillus thuringiensis in Phthorimaea Operculella (Zeller) (Lepetoptera: Gelechiidae) Baghdad. Sci. Journal. 2011; 8 (1): 7-12.

8. Charles S Pavia, Alexandra Pierre, Jon Nowakowski. Antimicrobial activity of nicotine against a spectrum of bacterial and fungal pathogens. J. Med. Microbiol. 2000; 49: 674-675.

9. Ruijie Huang, Mingyun Li, Richard L. Effect of nicotine on growth and metabolism of streptococcus mutans, Eur. J. Oral. Sci. 2012; 120 (4): 319-325.

10. Koppad, RG, Shivanna, N. Effect of nicotine on Larval hehaviour and fitness in Drosophila melanogaster. J. Biopesticide. 2010;3(1), 222-226.

11. Al-Jawhary, Ihsan. F. H. Effect of Acetone extracts to som plants on barley seeds- born Fungi in Musrata city. Thi-Qar Univ. J. Agr. Res. 2012;1(2):191-210.

12. Al-Naser ZA, Al-dden, D Ezz. Activity of some plant extracts against Alternaria alternate and Fusarium oxysporum and compared with fungicides in vitro .Tishreen Univ. J. Res. Sci. Stud. Biol. Sci. 2014; 36(3):31-46.

13. Mansk R.H.F. The alkaloids chemistry and physiology. Academic press, New york.1950.

14. Adnan M. Massadeh, Ahmad A. Gharaibeh, and Khaled W. Omari. A Single-Step Extraction Method for the Determination of Nicotine and Cotinine in Jordanian Smokers Blood and Urine Samples by PRHPLC and GC-MS. J of Chromatogr Sci. 2000; (47): 170-177.

15. Prakash chander, Tushar N Mehta. HPLC- UV Method for the Determination of Alkaloids Using a Syncronis aQ Column. Center of Excellence for Asia Pacific Lab. India .Retrieved on 2/1/2018.

16. K Tyrpien, C Dobosz, A. Chrosciewicz, M. Ciolecka , T. Wielkoszynski , B. Janoszka and D. Bodzek . Investigation of Nicotine transformation products by densitometric TLC and GC.Ms. Acta chromatogr .2003 ; 13(1): 154-160.

17. Smita N, Sushma M. Preliminary physicochemical and phytochemical evaluation of morinda citrifolia fruit extractives. Int. J. Pharm. Pharm. Sci. .2010 ; 2:150-154.

18. Wagner, Roland ; Feth , Friedhelm and Wagner, Karl $\mathrm{G}$. The regulation of enzyme activities of the nicotine 
pathway in tobacco. Physioloia Plantarum . $1986 ; 68$ (4) : 667-672.

19. Kokate, C.K.; Purohit, A.P., S.B. Gokhale. S.B. Pharmacognosy Nirali Prakashan . 2009; 6: 16-17.

20. Mahmoud, M.J. 2008 Chemistry of medicinal plants. printed in Anwar Dijla, Bagdad. 2008: 13-17.
21. Harris, Daniel C. Quantitative Chemical Analysis $6^{\text {th }}$ Edition . New York; W.H. Freeman. 2003.

22.C. M. Riley, I.W. Wainer, W.J. Lough. Pharmaceutical and Biomedical Applications of Liquid Chromatography, Science Ltd, Great Britain .1994 .

\section{فPLC فصل وتقدير النيكوتين المستخلص من الباذنجان والقلقل الاخضر بوساطة تقتية}

\section{زينب هاشم محمد}

قسم الكيمياء التطبيقية، كلية العلوم التطبيقية، جامعة سامر اء، سامر اء، العر اق.

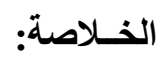

تم فصل وتقدير قلويد النيكوتين المستخلص من بذور الباذنجان وبذور الفلفل الاخضر( نباتات العائلة الباذنجانية ) بأستخدام تقنية

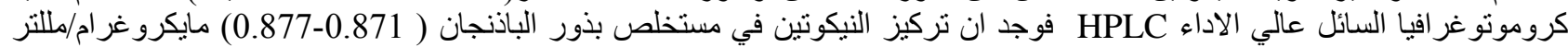

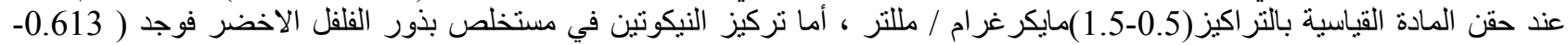

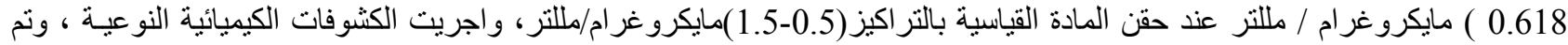

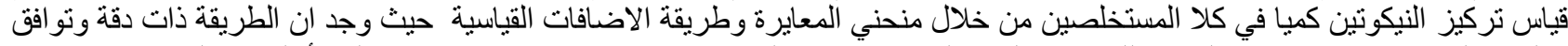

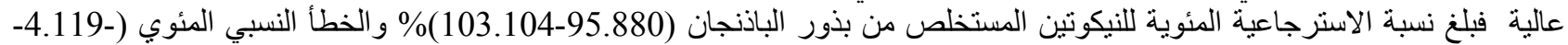

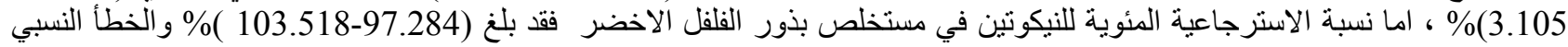
المئوي (3. (316) \%

الكلمات المفتاحية: نيكوتين، باذنجان، فلفل أخضر، HPLC، مستخلص 